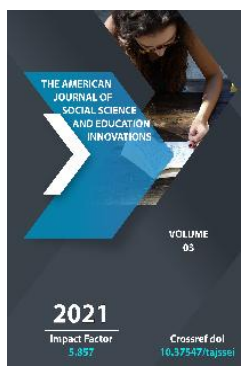

\title{
Combined In Technology Courses Use Of Technologies
}

Makhmatmurod Khuramovich Shomirzayev

Doctor Of Sciences, Associate Professor, Termez State University Termez, Uzbekistan

Journal Website:

http://theamericanjour

nals.com/index.php/taj

ssei

Copyright: Original content from this work may be used under the terms of the creative commons attributes 4.0 licence.

\section{ABSTRACT}

The article highlights the essence of the formation of creative abilities in students through the use of integrated technologies in the organization of practical lessons in school technology education.

\section{KEYWORDS}

School, technology, lesson, student, education, upbringing, practical, harmonized technology, pedagogical process, personality, activity, development, private, cognitive, creative, integrative, inversion, adaptive, inclusive, creativity, profession.

\section{INTRODUCTION}

As the President of our country Sh.M.Mirziyoev noted: "If we do not bring up our child properly, if we do not pay attention to his behavior and mood every day, every minute, if we do not teach them science, if we do not find a decent job, we will lose this deposit." ${ }^{1 .}$ 
In the current period of gradual implementation of reforms in the field of education in the country, based on the requirements of the National Training Program, there is a need to put into practice the existing conclusions and recommendations to improve the effectiveness of education. In particular, one of the main goals of the "National Training Program", which is being implemented in three stages, is to form competitive, active and creative individuals who can adapt to the transition to a market economy. Therefore, the Decree PF-6108 "On measures to develop education and science in the new period of development of Uzbekistan" signed by President Islam Karimov on November 6, 2020 also

states

${ }^{1}$ Mirziyoev Sh. Let us be more united and work resolutely for the fate and future of our country. // "Xalq so'zi" gaz., 2017, June 16.

that "with new initiatives and ideas for the development of the country which is new, with high intellectual and spiritual potential training of the next generation, formation of the necessary skills and knowledge for graduates of educational institutions to become modern professionals "is one of the main directions in this area. ${ }^{1}$ This issue, along with other disciplines, is a key task in the teaching of technology. This requires the effective and rational use of teaching methods in the teaching process, as well as the improvement of these methods, the search for new ones, increasing the effectiveness of technology education. Therefore, the main issue in the field of education today is the well-mastered methods and forms of education, training of qualified teachers who can easily apply them in practice. Because the teacher's personality and his activity are of special importance in educating students, directing them to professions. Consequently, nothing else can overwhelm the teacher's open communication-style learning process. Therefore, improving the quality and effectiveness of education is an important factor for the training of qualified teachers, to improve their professional skills.

At present, a number of researchers have developed general indicators of pedagogical technologies, such as appearances, directions, principles, criteria, and ways to use them. For example, in the manual of J.Yuldashev and S.Usmanov "Fundamentals of pedagogical technology" the following are the main directions of pedagogical technology $[5,236]$ :

- current traditional education (XVII didactic of Ya.A. Comenius in the century formed on the principles of and is currently the most widely used in schools consists of a class-lesson system. This is mainly modern pedagogical technologies created to improve the system in various areas, is currently evolving);

- Improving the pedagogical process, directing it to the student rish-based pedagogical technologies (хамкорлик педагогикаси, таъ-лимнинг инсонпарварликка асосланган технологияси ва бошқалар);

${ }^{1}$ Decree of the President of the Republic of Uzbekistan "On measures for the development of education and science in the new period of development of Uzbekistan." T., November 6, 2020 PF-6108

- pedagogical technologies based on activation and acceleration of student 
activity (problem-based learning, games, base signal abstract technologies, etc.),

- pedagogical technologies based on didactic improvement and revision of teaching materials (these technologies are based on the principles that the didactic system of knowledge taught has a deep meaning, a systematic approach to knowledge, teaching students the most appropriate ways of acquiring knowledge);

- pedagogical technologies based on effective management and organization of the educational process (these technologies are stratified, individualized, programmed learning technologies; collective method of education, group, computer learning technologies, etc.);

- nature-adapted pedagogical technologies (these include pedagogical technologies based on the realization of the full potential of the student, the natural capacity of the organization of the educational process and other opportunities in accordance with nature);

- developmental learning technologies (these include technologies for developing the positive qualities of the student's personality, knowledge in certain areas, creative abilities;

- private (educational sciences), alternative - alternative, authorship, empirical (learning through intuition);

- cognitive (technology to expand the scope of knowledge about the surrounding world);

- heuristic (a system of teaching through reference questions);

- creative (has a research nature and rapidly develops goal-oriented creative thinking in students);
- inversion (has the ability to study information from different angles, to change places, to think (thinking) forms the system);

- integrative (determine a single correct conclusion based on the interdependence of an infinite number of small parts that make up information, their integrity, integrity);

- adaptive ( study the information and the process of its use as well as facilitation for training, adaptation is expected, reach the jaw);

- inclusive (organization of the educational process on the basis of equality in the relationship between teacher and student).

In our research, we used pedagogical technologies based on the activation and acceleration of student activities, developmental educational technologies, heuristic, creative, integrative, as well as pedagogical technologies that combine some of their elements. And the pedagogical technologies formed by the combination of the above pedagogical technologies integrated technologies we called. Also, one of the peculiarities of technology lessons is that in practical classes students learn the structure and use of equipment and machinery, types, structure, properties and uses of materials, as well as the manufacture of any product. In doing so, they work directly on the basis of production technologies, ie technical technology. In order to carry out this work in accordance with the purpose, they are given theoretical information, concepts and instructions before the practical training. In this case, teaching technologies are used. It is obvious that the use of both teaching technologies and technical technologies is 
required during a single practical training in the subject of technology education. This is also the case in technology classes the need to use integrated technologies causes. This is especially useful in organizing the creative activities of students. Because creative activity requires a creative approach to the task at hand. This requires the development of students' skills such as comprehension, imagination and practical work, which is why integrated technologies serve this purpose. Thus, Integrated technologies are educational technologies that consist of a combination of parts of teaching and technical technologies aimed at students' creative thinking and practical work, we understand.

Now we will focus on how these combined technologies can be used in the organization and development of creative activity of students in technology science classes.

As mentioned above, technology classes in general secondary schools are one of the longest-lasting subjects in the school with the teaching from the 1st grade to the last grade and are the main, leading tool in directing students to work and career choice.

Experience has shown that most students in grades I-IV like to make mistakes. They strive to do something like adults. He wants to make his wishes come true. This is what drives students to the school learning workshop. During breaks and after classes, they rush to see how older students are doing. Finally, as the days go by, the 5 th graders come into the training workshop. During this period, children become very curious and diligent. As the years go by, the former 5 th graders grow from class to class. Their curiosity and diligence are slowly fading. Because in children of this age, the "transition period" begins. The "transition period" in children, according to the Swiss psychologist Jean Piaget, is associated with the development of abstract ideas about the object and existence in general. The complexity of thinking activities affects all aspects of a child's life, his or her emotions.

According to American psychologist Eric Erickson, a child develops a sense of "entrepreneurship" and "sensitivity" in the pursuit of his goals. At this age, the basis of the attitude to labor is formed.

The children's fantasy of the "transition period" begins. Taking into account the different mental states of students in the "transition period" the effectiveness of organized education increases. In methodology and pedagogical psychology, great importance is attached to the selection of the best methods of teaching, the use of factors that enhance the cognitive activity of students in the educational process.

Our observations show that in many cases, teachers 'use of the same methods in conducting lessons reduces students' interest in the science of technology.

In order to prevent this, ensuring the diversity of students' activities in the classroom is one of the main tasks of technology, as well as many other subjects.

In secondary schools, advanced, experienced, creative teachers use non-traditional methods, such as tests, seminars, conferences, quizzes, tests, theatrical lessons, which meet the requirements of modern lessons. Conducting non-traditional teaching and learning in the field of technology has a significant impact on the formation of creativity, curiosity and independent thinking skills of students. One of such activities is to conduct generalization- 
repetition lessons as a modern (nontraditional) lesson after studying the topics in some sections of the curriculum for grades $\mathrm{V}$ VII. Therefore, the achievement of high efficiency in teaching depends on the selection of teaching methods that are appropriate to the types, types and forms of lessons, ie educational technologies and how to apply them. Technology classes are divided into two parts, theoretical and practical. In providing theoretical information or insights, teaching materials are narrated to students in a way that includes storytelling, conversation, explanation, and partial presentation methods. In the practical classes, students are taught the structure of equipment, mechanisms and machines, their adjustment to work, their use and performance of work operations, and the manufacture of a part or item. Which pedagogical technologies to use in these lessons is chosen depending on the nature and purpose of the lesson. Forms of teaching in technology are such as lessons (practical training), student brigade, attachment to the work brigade, attachment of students to skilled workers, production practice of students in full-time jobs, training of students in workshops and special areas, technical circles. Typically, these course forms are implemented in individual (individual), group (link), group (frontal) forms.

The pedagogical literature describes the classifications of course types developed by most pedagogical researchers. These are based on the purpose of the lesson, the activities of the teacher and the students. For example, J. Ramizov's textbook on "Methods of teaching general technical subjects and labor education", published on the subject of technology (labor education) teaching methods, gives the following types of labor education - technology lessons [7, 207]:

1. Introduction lesson.

2. New knowledge lesson.

3. Graphic concept and knowledge transfer lesson.

4. Lesson on terms of reference and design.

5. Lesson of technological practice and technological exercises.

6. Lessons of laboratory and laboratorypractical work.

7. Film demonstration lesson.

8. Excursion lesson.

9. A lesson on repetition.

10. By programming and using hardware teaching lesson.

11. A lesson on independent investigation.

Similar types of courses are also described in the textbooks on labor (technology) and methods of teaching vocational education, published under the leadership of DMT horzhevsky and KD Davlatov, J.Mirsaidov. Based on the study of these guidelines and the results of the experiment, in order to facilitate the use of compatible technologies in the organization and development of creative activity of students in technology classes, there are four main types of technology classes, i.e 1) introductory classes; 2) to impart new knowledge, labor skills classes; 3) repetition-strengthening lessons; 4) We came to the conclusion that it is convenient to use the types of test courses and chose the appropriate technologies to suit them. For example, in introductory classes short speech, conference, discussion; to impart new knowledge, to form work skills mental attack, creative issues, morphological table, seminar, discussion, mosaic, training, relay; repetition-strengthening role-playing in classes, conference, cheerful and clever 
competition, business game (auction lesson); in test classes эca and "What, when, where" game, test question, interview, competition lesson, exhibition lesson. Based on the results of our research, we tried to describe it as shown in table 1 (see Table 1 ).

1-table. Course types and compatible technologies

\begin{tabular}{|c|c|c|}
\hline T/r. & Course types & Coordinated technologies used \\
\hline 1 & Introductory classes & Short speech, conference, discussion, etc. \\
\hline 2 & $\begin{array}{c}\text { Giving new knowledge, } \\
\text { developing work skills }\end{array}$ & $\begin{array}{r}\text { Brainstorming, creative problem, morphological table, } \\
\text { seminar, discussion, mosaic, BBB, training, relay and so on. }\end{array}$ \\
\hline 3 & Repetition & $\begin{array}{r}\text { Role-playing, conference, cheerful and clever contest, } \\
\text { business game (auction lesson), etc. }\end{array}$ \\
\hline 4 & lessons & $\begin{array}{r}\text { That, when, where "game, test questionnaire, competition } \\
\text { lesson, exhibition lesson, interview, etc. }\end{array}$ \\
\hline
\end{tabular}

It is obvious that due to the current stage of development of the concept of pedagogical technology, there is a need to determine the types of lessons according to the content and purpose of teaching technology, the selection of appropriate educational technologies, as well as classification. As one of these, we tried to use the concept of harmonized technologies. Above in the next There are recommendations for the use of certain methods that allow the use of harmonized technologies appropriate to the types of courses mentioned.

It should be noted that, unlike other disciplines in secondary schools, they have great potential in the formation of creative abilities by increasing the activity of students in technology classes. This is because theoretical education in technology science is inextricably linked with practical education. This allows students to work independently, to demonstrate their abilities at the level of opportunity. Students are happy to see what they have created during the lesson, compare it with what their peers have made, be proud of their achievements, and correct any shortcomings. This will be the first step in developing students into independent individuals. In organizing such work, the skill of the teacher, in particular, the choice and application of forms and methods of teaching, depending on the appearance of the lesson, is important.

One of the important aspects of teaching technology is to teach students to do practical work independently and creatively in the classroom.

From the above information, it is clear that teaching and educating students is hard work. One of the most difficult tasks of a teacher is to achieve the active participation of all 
students in the lessons, taking into account the individual characteristics of each student. It is important to keep in mind that student activity does not increase spontaneously, but is the result of a conscious attitude. Since activity arises as a result of consciousness, it requires the coordination of the content, form of organization, methods and means of implementation of educational work. The teacher should try to consciously increase the interest of students in reading.

\section{REFERENCES}

1. Mirziyoev Sh. Let us be more united and work resolutely for the fate and future of our country. // "Xalq so'zi" gaz., 2017, June 16.

2. Decree of the President of the Republic of Uzbekistan "On measures for the development of education and science in the new period of development of Uzbekistan." T., November 6, 2020 PF6108

3. Azizxo'jaeva N.N. Pedagogical technology and pedagogical skills: Textbook. - T .: TDPU, 2003. - 174 p.

4. Babanskiy Yu.K. Teaching methods in modern general education school. $\mathrm{T}$.: Teacher, 1990. - 232 p.

5. Yuldashev J.G., Usmanov S.A. Fundamentals of pedagogical technology. $\mathrm{T}$.:Teacher, 2004. - $236 \mathrm{p}$.

6. Karimov I., Shomirzaev M. Innovative pedagogical technologies in teaching technology: Textbook. T .: Universitet, 2020. - 190 p.

7. Ramizov J.R. Methods of teaching general technical subjects and labor education. T., Teacher, 1982. - $207 \mathrm{p}$.

8. Saidahmedov N. New pedagogical technologies (theory and practice).

T., Finance, 2003.

9. Sattorova $Z$ and b. Technology: Textbook, 9 p. T .: Uzbekistan. - 160 b.

10. Farberman B.L. Advanced pedagogical technologies. T.: Fan, 2000. - 125 b.

11. Shomirzaev M.X. Theory and practice of interdisciplinary improvement of spectral- variable components of national crafts in school technology education. Monograph. - T .: Tafakkur, 2020. - 164 p.

12. Shomirzaev M.X. Factors of interdisciplinary formation of students' interest in folk crafts // School and life. - T., 2019. - 6-son. - B. 23-24.

13. Shomirzaev M.X. The use of educational technologies in the formation of students' interest in the professions of national crafts // Karakalpak State University Bulletin. - Nukus, 2019. - 4 (45) -son. - B. 98102.

14. Shomirzaev M.X. Vocational education: national embroidery // Pedagogy. - T. 2019. - 3-son. - B.122-129.

15. Shomirzaev M.X. Opportunities for the integration of sciences in the formation of students' interest in the professions of national crafts // Science and society (Science and society). - Nukus, 2019. - 3rd issue. - B. 106-108.

16. Shomirzaev M.X. Improving the orientation of students to the professions of folk crafts in technology education // Science and society (Science is also society). - Nukus, 2020. - 2-son. - B. 98-100.

17. Shomirzaev M.X. Psychological and pedagogical potential of folk crafts in school technology education // Tafakkur ziyosi. - Jizzax, 2020. - Issue 4. - B. 154-155.

18. Shomirzaev M.X. Problem-based education in the lessons of "Technology" // Modern education. - Tashkent, 2020. Issue 6 (91). - B. 28-35.

19. Shomirzaev M.X. The use of modern teaching methods in teaching schoolchildren folk crafts // Teacher and continuous education. - Nukus, 2020. - 2nd issue. - B. 42-46.

20. Shomirzayev, M.Kh. (2019). The ethical characterics of traditional embroidery of Fergana valley people. European Journal of Research and Reflection in Educational Sciences, 7 (12). - P. 55-59.

21. Shomirzayev, M.Kh. (2020). Education is personaly focused technology. European 
Journal of Research and Reflection in Educational Sciences, 8 (8), Part. 93-99.

22. Shomirzayev, M.Kh. et al. (2020). National handicrafts of Uzbekistan and its social economic significance. European Journal of Research and Reflection in Educational Sciences, 8 (8), Part III. 129-138.

23. Shomirzayev, M.Kh. (July, 2020). Technology of Educational Process in School Technology Education. The American Journal of Social Science and Education Innovations. Impact Factor 5.366. - - № $02 . \quad$-P. $212 \quad-\quad 223$. (www/usajournalshub.com/index.php/tajs sel).

24. Shomirzayev, M.Kh. (30 July, 2020). Developing Educational Technologles in School Technology Education. The American Journal of Social Science And Education Innovations, Impact Factor 5.26. -P.II/VII 51 57. (www/usajournalshub.com/index.php/taje t).

25. Shomirzayev, M.Kh. The Concept Of Pedagogical Technology And Basic Principles. Academicia: An International Multidisciplinary Research Journal. (Affiliated to Kurukshetra University, Kurukshetra, India), Vol. 10, Issue 11, November 2020 Scientific Journal Impact Factor (Sjif 2020-7.13). -Part 1554 - 1563. (https://saarj.com)

26. Shomirzayev, M.Kh. (2020). Ethnic characteristics of national traditional crafts. European Journal of Research and Reflection in Educational Sciences, 8 (12). P. 216-225.

27. Shomirzayev, M.Kh. (2020). "Technology" In Secondary Schools Organization of Science Classes. The American Journal of Social Science and Education Innovations, Impact Factor 5.525 (11). -P. 395-405. (www/usajournalshub.com/index.php/taje t).

28. Lisa A. Moyer, Engaging Students in 21st Century Skills through NonFormal Learning, Dissertation submitted to the faculty of Virginia Polytechnic
Institute and State University, Blacksburg, Virginia, The USA, March 10, 2016. 